\section{Resistance to Fusarium wilt in common bean}

\author{
Renata Oliveira Batista ${ }^{1,2^{*}}$, Ana Maria Cruz e Oliveira², Johnn \\ Lennon Oliveira Silva ${ }^{2}$, Alessandro Nicoli ${ }^{1}$, Pedro Crescêncio \\ Sousa Carneiro ${ }^{3}$, José Eustáquio de Sousa Carneiro ${ }^{2}$, Trazilbo \\ José de Paula Júnior ${ }^{4}$ and Marisa Vieira de Queiroz ${ }^{5}$
}

\begin{abstract}
In breeding programs, understanding the potential of parents should be a way to spend significantly less time and costs to obtain new cultivars. For this, the objective of this study was to estimate the general and specific combining ability of parents aiming common bean breeding for resistance to Fusarium wilt (FW) based on disease severity and reduction in plant growth. Eight common bean genotypes were crossed in a $3 \times 5$ partial diallel mating scheme to obtain $F_{1}$ hybrids. The parents and their $15 F_{1}$ hybrids were evaluated for severity of Fusarium wilt, area under the disease progress curve, percentage of plant height reduction and plant shoot fresh weight reduction and grain yield. The resistance of common bean to FW is controlled by a few dominant genes. The reduction in plant growth is controlled by a different set of genes that can increase the selection efficiency of parents for common bean breeding.
\end{abstract}

Key words: Genetic control, breeding for resistance, Fusarium oxysporum $f$. sp. phaseoli.

\section{INTRODUCTION}

Fusarium oxysporum Schlecht., a widespread soil pathogen, causes vascular wilt in more than 100 plant species and is considered one of the 10 economically and scientifically most important pathogenic fungi in the world (Dean et al. 2012, Pantelides et al. 2013). In Brazil, Fusarium oxysporum f. sp. phaseoli (Fop) occurs in almost all common bean-producing areas (Toledo-Souza et al. 2012), reducing the yield significantly. According to Ramalho et al. (2012), this happens due to successively adoption of Fop-susceptible cultivars, which is hampering common bean cultivation under center pivot irrigation in several producing areas.

At Fop-free areas, the pathogen is generally introduced by infected seeds and contaminated agricultural implements. It survives either as a saprophyte or through the production of chlamydospores, which remain in the soil for many years. The integrated disease management of Fusarium Wilt (FW) is limited to crop rotation, seed treatment and use of resistant cultivars. Cross et al. (2000) and Pereira et al. (2009) stated that the use of resistant cultivars is the most effective method of controlling the economic losses caused by Fusarium wilt.

The severity of Fusarium wilt in common bean is usually assessed by a grade scale developed by Pastor-Corrales and Abawi (1987), based on the symptom of plant canopy wilting as main criterion. However, Pereira et al. (2013) reported
Crop Breeding and Applied Biotechnology 16: 226-233, 2016 Brazilian Society of Plant Breeding. Printed in Brazil http://dx.doi.org/10.1590/1984$70332016 v 16 n 3 a 34$ 
that aside from wilting, the plant is affected by stunted growth in some Fop-infected bean cultivars. To assess this trait by quantifying the rate of stunted growth, plants of the same genotype are used as negative control (uninoculated), which restricts the evaluation to genotypes with high degree of uniformity (lines or hybrids).

Hybridization is a method used in bean breeding and an accurate selection of the parents for crossing is decisive to determine the success of the program (Ramalho et al. 2012). In diallel crosses, the general and specific combining ability can be estimated, and the predominant genetic control of the trait can be determined.

There are no reports of the use of stunted plant growth as a response of Fop susceptibility neither for choice of common bean parents to Fusarium wilt resistance. Thus, our objective was to estimate the general and specific combining ability of parents for common bean breeding for resistance to Fusarium wilt, based on disease severity and reduced plant growth.

\section{MATERIAL AND METHODS}

\section{Plant material}

Cultivars and elite lines of carioca bean with upright growth habit or high yield potential were chosen for group 1 of the partial diallel (BRS Estilo, VC 13 and VC 25). Group 2 included putative Fop-resistant genotypes BRSMG Talismã, CVIII 8511, Pérola, RC-I-8 and CNFC 11965. The diallel crosses were made by hand-pollinating the female parents without emasculating (Peternelli and Borém 1999). The crosses were made in a greenhouse, in a 3 x 5 partial diallel, in 2013, resulting in $15 F_{1}$ hybrids. In stage $R 9, F_{1}$ seeds were harvested and stored for later experiments.

\section{Evaluated traits}

\section{Reaction to Fop}

In the greenhouse, the eight parents and their $15 \mathrm{~F}_{1}$ hybrids (totaling 23 treatments) were evaluated for Fop resistance. The experimental design was completely randomized with three replications in experimental units consisting of one pot with three plants.

The isolate FOP UFV 01 was collected from plants of the common bean cultivar Meia Noite with typical Fusarium wilt symptoms, in Coimbra (Minas Gerais, Brazil) (Pereira et al. 2013). Pereira et al. (2013) inoculated FOP UFV 01 in differential cultivars of beans, proposed by Woo et al. (1996) and Alves-Santos et al. (2002), and concluded that this isolate is a new race of the species. FOP UFV 01 inoculum was produced with PDA (potato - dextrose - agar) discs containing mycelia that were transferred to Petri dishes containing PDA. The plates were maintained for 14 days in a growth chamber at $25 \pm 1$ oC, under a 12-h photoperiod. The spore suspension was prepared one hour before inoculation at a concentration of 1 $\times 10^{6}$ conidia $\mathrm{mL}^{-1}$, including macro and microconidia, as recommended by Pastor-Corrales and Abawi (1987).

To inoculate the genotypes, the roots were immersed in a conidia suspension, as proposed by Pastor-Corrales and Abawi (1987). In order to do so, seeds of the 23 genotypes were sown in 128 cell-trays containing Topstrato ${ }^{\circledR}$ vegetable substrate, and maintained in a greenhouse for germination and seedling growth. In stage V2 (fully expanded primary leaves), the seedlings were carefully removed from the trays, the roots were washed and $1 / 3$ of their length was cut off. Immediately after cutting, the seedling roots were immersed in the macro and microconidia suspension of isolate FOP UFV 01 for $5 \mathrm{~min}$. Thereafter, the seedlings were transplanted to plastic pots containing 2.5 L Topstrato ${ }^{\circledR}$ substrate and maintained in a greenhouse at $25 \pm 3 \circ \mathrm{O}$. The plants were irrigated daily and 10 days after inoculation (DAI), each pot was fertilized with $1.0 \mathrm{~g}$ urea as $\mathrm{N}$ source.

The reaction of genotypes to Fusarium wilt was evaluated in grades on a 1-9 disease severity scale, as described by Pastor-Corrales and Abawi (1987), based mainly on shoot wilting intensity, where: $1=$ no visible symptoms; $3=1 \%$ to $10 \%$ of symptomatic leaves (leaves with mild chlorosis and wilting); $5=11 \%$ to $25 \%$ of symptomatic leaves (leaves with moderate chlorosis and wilting); $7=26 \%$ to $50 \%$ of symptomatic leaves (leaves with severe wilting and chlorosis) and 9 = dead or severely infected plant. The plants were assessed 15, 18 and $21 \mathrm{DAl}$, and the severity grade of Fusarium wilt in the last assessment (SFW) was used to classify genotypes for Fusarium wilt reaction. As suggested by Pastor-Corrales and Abawi (1987), the reaction of genotypes with a mean grade between 1.0 and 3.0 was considered resistant, from 
3.1 to 6.0 intermediate and 6.1 to 9.0 susceptible.

The area under the disease progress curve (AUDPC) was calculated as proposed by Shaner and Finney (1977), in three assessments, as follows:

$A U D P C=\sum_{i=1}^{n}\left[\left(\frac{Y_{i+1}+Y_{i}}{2}\right)\left(T_{i+1}-T_{i}\right)\right]$ where:

$Y_{i}=$ severity of Fusarium wilt at the $i^{\text {th }}$ observation,

$\mathrm{T}_{\mathrm{i}}=$ time (days after inoculation) at the $\mathrm{i}^{\text {th }}$ observation and

$\mathrm{n}=$ total number of evaluations.

\section{Reduction in plant growth}

The reduction in plant growth was assessed by reduction in plant height and fresh weight of the plant shoot. To this end, six seedlings of the same genotype were inoculated with FOP UFV 01 and $1 / 3$ of their roots was cut off and immersed in distilled water for $5 \mathrm{~min}$ and transplanted into two pots, as a negative control. In this case, two replications and plots of one pot with three plants were used. After the last disease severity evaluation, one plant per pot of the FOP UFV 01-inoculated plots as well as of the negative control was cut and the height measured from the cotyledon node to the insertion of the last leaf, expressed in centimeters $(\mathrm{cm})$. Then, each plant was wrapped separately in a paper bag and weighed to determine the shoot fresh weight (grams). The percentage of plant height reduction (PHR) and plant shoot fresh weight reduction (PSWR) in FOP UFV 01-inoculated plants, for each replication, was calculated from the mean height and fresh weight measured in the negative control plants, as follows:

PHR/PSWR $=\frac{\left(Y_{i c}-Y_{i}\right) \times 100}{Y_{i c}}$, where:

$Y_{i c}=$ mean height or fresh weight of the shoot of genotype i plants inoculated in distilled water (negative control) and

$Y_{i}=$ mean height or fresh weight of the shoot of genotype i plants inoculated with FOP UFV 01.

\section{Grain yield}

Grain yield (GY) was measured in a field experiment at the Experimental Station in Coimbra city (lat 20 $45^{\prime} \mathrm{S}$, long $42^{\circ} 51^{\prime} \mathrm{W}$, alt $690 \mathrm{~m}$ asl). Seeds of the eight parents and their $15 \mathrm{~F}_{1}$ hybrids (totaling 23 treatments) were sown in the 2014 dry season in a randomized block design with three replications. The plots consisted of two 1.5-m rows, spaced $0.50 \mathrm{~m}$ apart, with a planting density of 12 seeds per meter. At the time of harvest, all plants of the plot were cut by hand and the grains processed and weighed to determine grain yield in $\mathrm{kg} \mathrm{ha}^{-1}$. Note that no incidence of Fusarium wilt was detected in this season.

\section{Genetic-statistical analyses}

For the diallel analysis of SFW, AUDPC, PHR, PSWR and GY, the model of Griffing (1956) adapted to partial diallel was adopted, according to the following model:

$Y_{i j}=\mu+g_{i}+g_{j}^{\prime}+s_{i j}+\bar{\varepsilon}_{i j}$ where

$\mathrm{Y}_{\mathrm{ij}}=$ mean value of the hybrid combination between the $\mathrm{ith}^{\text {th }}$ parent of group I and the $\mathrm{j}^{\text {th }}$ parent of group II; $\mu=$ overall mean of the diallel; $g_{i}=$ effect of general combining ability of the $i^{\text {th }}$ group $1 ; g_{j}^{\prime}=$ effect of general combining ability of the $j^{\text {th }}$ group of parent $2 ; \mathrm{s}_{\mathrm{ij}}=$ effect of specific combining ability between parents of order $\mathrm{i}$ and $\mathrm{j}$, of groups 1 and 2 , respectively, and $\bar{\varepsilon}_{i j}=$ mean experimental error. All genetic statistical analyses were performed with the software Genes (Cruz 2013).

\section{RESULTS AND DISCUSSION}

\section{Performance of parents and $F_{1}$ hybrids}

For the degree of SFW, the parents VC 13 and VC 25 from group 1, and BRSMG Talismã and CVIII 8511 of group 2 showed excellent performance, in terms of resistance to FOP UFV 01 (score $=1$ ). Parent Pérola was also noteworthy 
(degree $=1.67)$ (Table 1). The other parents showed a reaction of susceptibility to Fop (scores $>7.7)$. Resistance is dominant to susceptibility based on the performance of the F1's. All families with one resistant parent produce resistant F1 progeny $(R \times R$ or $R \times S)$. All susceptible by susceptible crosses produced susceptible progeny $(\mathrm{S} \times \mathrm{S})$. This is exactly what is expected from crosses between parents with dominant resistance genes. Other authors also observed dominance in the genetic control of Fusarium wilt resistance. Pereira et al. (2009) evaluated six crosses involving three resistant and four susceptible lines, and observed complete dominance in Fop resistance genetic control in common bean. The same result was reported by Cross et al. (2000) for two $\mathrm{F}_{2}$ generations of crosses between Fop-resistant and Fop-susceptible Durango common bean parents.

The results of AUDPC for Fop reaction agreed with those of the SFW indicating that only the assessment at 21 days was sufficient to determine Fop severity and reaction (Resistant, Intermediate and Susceptible). Fop severity in common bean is usually evaluated only at 21 or 22 days (Pastor-Corrales and Abawi 1987, Cândida et al. 2009, Pereira et al. 2009). However, in evaluations performed in different years, at different locations and under different managements, as reported by Madden et al. (2007), the AUDPC proved effective to differentiate genotypes.

Considering the rate at which the growth of the parents is stunted, the percentage PHR and PSWR at Fop-susceptible plants was high, ranging from 43 to $63 \%$ (Table 1). Among the resistant parents, stunted growth comportment was different. For the parents VC 13, BRSMG Talismã and CVIII 8511, a PHR and PSWR of up to 11.11\% was observed, while for VC 25 and Pérola, which are also resistant, the growth reduction rate was higher, ranging from 18 to $26 \%$. The performance of the parents and hybrids for growth stunted measured by the PHR and PSWR in disagreement with Fop-resistance

Table 1. Means of parents and their $F_{1}$ hybrids for severity of Fusarium wilt (SFW), area under the disease progress curve (AUDPC), percentage of plant height reduction (PHR), percentage of shoot fresh weight reduction (PSWR), and grain yield (GY)

\begin{tabular}{|c|c|c|c|c|c|c|}
\hline & Parents & SFW & AUDPC & PHR (\%) & PSWR (\%) & GY $\left(\mathrm{kg} \mathrm{ha}^{-1}\right)$ \\
\hline & \multicolumn{6}{|l|}{ Group 1} \\
\hline 1 & BRS Estilo & 8.33 & 39.00 & 43.75 & 58.40 & 4195.51 \\
\hline \multirow[t]{2}{*}{3} & VC 25 & 1.00 & 6.00 & 25.74 & 21.09 & 4944.86 \\
\hline & Group 2 & & & & & \\
\hline 3 & CVIII 8511 & 1.00 & 6.00 & 4.76 & 02.52 & 4180.92 \\
\hline 4 & CNFC 11965 & 8.50 & 37.50 & 63.72 & 60.10 & 3830.17 \\
\hline 5 & Pérola & 1.67 & 7.00 & 19.33 & 18.55 & 3950.71 \\
\hline \multicolumn{2}{|c|}{ Mean } & 3.69 & 17.06 & 28.00 & 26.00 & 4156.79 \\
\hline & Hybrids & & & & & \\
\hline 4 & BRS Estilo x CNFC 11965 & 9.00 & 45.25 & 54.95 & 57.68 & 4011.69 \\
\hline 5 & BRS Estilo x Pérola & 1.00 & 6.00 & 53.79 & 56.20 & 5627.19 \\
\hline 6 & VC 13 x BRSMG Talismã & 1.00 & 6.00 & 14.73 & 20.16 & 4201.39 \\
\hline 7 & VC $13 \times$ RC-I-8 & 1.00 & 6.00 & 30.13 & 43.48 & 4787.72 \\
\hline 8 & VC 13 x CVIII 8511 & 1.00 & 6.00 & 17.02 & 12.49 & 4532.40 \\
\hline 9 & VC 13 x CNFC 11965 & 1.00 & 6.00 & 37.31 & 41.05 & 4604.43 \\
\hline 10 & VC 13 x Pérola & 1.00 & 6.00 & 19.22 & 19.06 & 4669.39 \\
\hline 11 & VC 25 x BRSMG Talismã & 1.00 & 6.00 & 18.33 & 27.87 & 4689.64 \\
\hline 12 & VC $25 \times$ RC-I-8 & 1.00 & 6.00 & 44.14 & 53.53 & 4773.31 \\
\hline 13 & VC 25 x CVIII 8511 & 1.00 & 6.00 & 09.43 & 06.04 & 4643.84 \\
\hline
\end{tabular}


assessed by SFW or AUDPC indicates that the genetic control of stunted growth is more complex, being controlled by a set of dominant and recessive genes. Thus, the results of SFW compared with the PHR and PSWR indicate that the genes involved in Fusarium wilt resistance are probably not those involved in stunted growth. These results also show that the traits PHR and PSWR, in addition to SFW, can potentially be used in the selection and discrimination of parents for Fop resistance.

With regard to the growth reduction rate of the hybrids, in general, hybrids resulting from crosses involving at least one parent with high PSWR and PHR values also had a high reduction rate, e.g., hybrids 1, 2 3, 4, 5, 7, 10, 11, and 12 (Table 1). The hybrids 9 to 14, however, resulting from crosses of CNFC 11965 with VC 13 and VC 25, had stunted growth with values close to the mean growth reduction rate of their parents. Hybrids 6 and 8, derived from parents that are resistant and have low growth reduction, had higher reduction rates than their parents. Hybrid 15 resulting from a cross between VC 25 and Pérola, both of which are resistant and have high reduction rates, had a high reduction rate as well. However the growth reduction in hybrid 13, resulting from a cross between VC 25 (resistant with a high reduction rate) with CVIII 8511 (resistant with a low reduction rate) was lower. These divergent results evidence the complexity of genetic control of growth reduction rate of common bean in Fop infection.

The mean grain yield of the parents $\left(4156.79 \mathrm{~kg} \mathrm{ha}^{-1}\right)$ and their hybrids ( $4816.76 \mathrm{~kg} \mathrm{ha}^{-1}$ ) exceeded the national mean $\left(1512 \mathrm{~kg} \mathrm{ha}^{-1}\right)$ for this growing season. There was no incidence of Fusarium wilt in the evaluation experiment of grain yield of parents and their $F_{1}$ hybrids. This trait will be studied in more detail in the diallel analysis.

\section{Diallel analysis}

The treatments had a significant effect $(p<0.01)$ on the traits SFW, AUDPC, PHR, PSWR, and GY (Table 2). Sum of squares of treatments was partitioned into effect of parents, hybrids and parents vs. contrast hybrids (Table 2). The effect of parents of groups 1 and 2 was also significant $(p<0.05)$ on all traits, except for GY, for group 2 informing that, for the significant traits, there is variability between parents in the frequency of favorable alleles involved in the genetic control of the traits under study. The effect of G1 in comparison with G2 on the traits SFW, PHR, PSWR, and GY was significant $(p<0.05)$ and non-significant on AUDPC.

The effect of hybrids was significant for all traits, indicating variability among the 15 hybrids ( $F_{1}$ generation). This effect of hybrids was partitioned into effects of general combining ability $\left(\mathrm{GCA}_{1}\right.$ and $\left.\mathrm{GCA}_{2}\right)$ and specific combining ability (SCA), which were significant for all traits (Table 2). The significance of the effects of general combining ability indicates that there is a difference in the frequency of favorable alleles between the parents of that group, while the significance of SCA indicates the presence of dominance deviations in the genetic control of the traits under study.

Table 2. Analysis of variance and diallel of the parents in groups 1 and $2\left(G_{1}\right.$ and $\left.G_{2}\right)$ and their hybrids for severity of Fusarium wilt (SFW), area under the disease progress curve (AUDPC), percentage of plant height reduction (PHR), percentage of shoot fresh weight reduction (PSWR) and grain yield (GY)

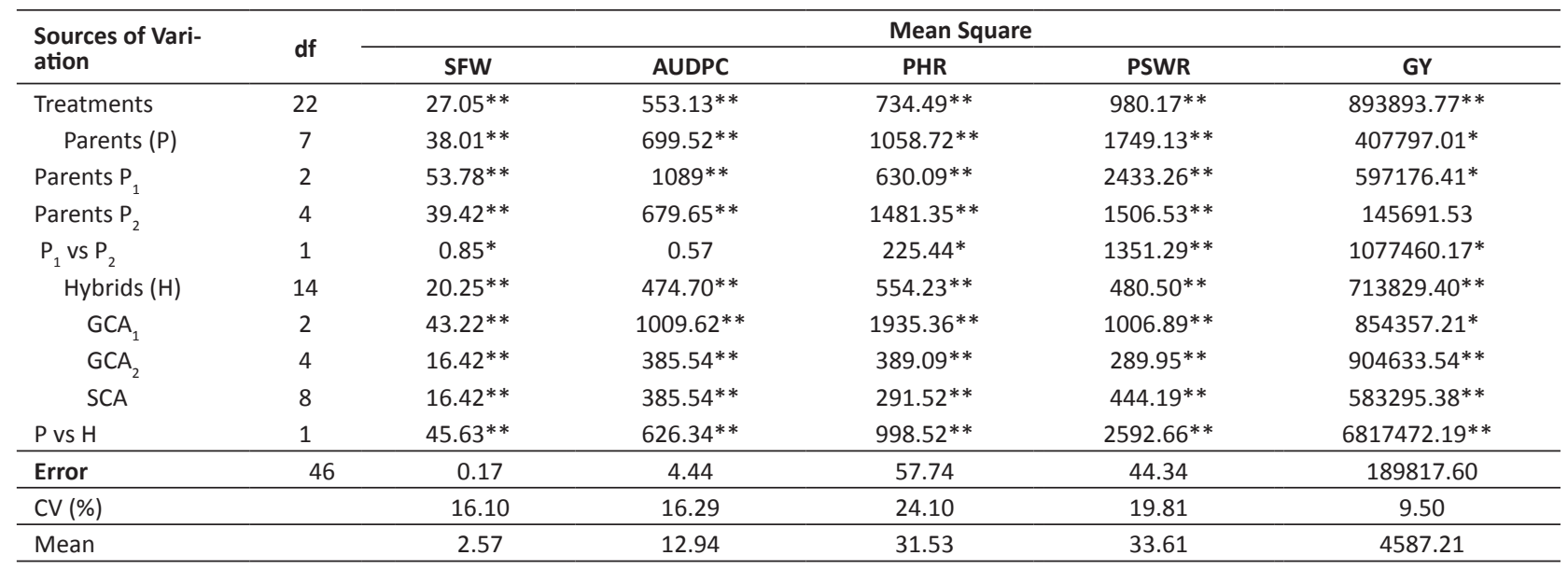

$\mathrm{df}$ - degree of freedom. ${ }^{*}, *$ Significant at $5 \%$ and $1 \%$ probability, respectively, by the $\mathrm{F}$ test. 
The sum of squares of the GCA $\left(\mathrm{GCA}_{1}+\mathrm{GCA}_{2}\right)$ compared to the sum of squares of SCA was similar for the traits SFW, AUDPC, PSWR and GY in magnitude, indicating a predominance of genes with complete dominance in the control of these traits. For the trait PHR, the sum of squares of the GCA $\left(\mathrm{GCA}_{1}+\mathrm{GCA}_{2}\right)$ exceeded that of SCA, with percentages of $70 \%$ and $30 \%$, respectively, indicating predominance of genes with additive effects in the genetic control of this trait.

\section{General combining ability}

The parents VC 13, VC 25, BRSMG Talismã, CVIII 8511, and Pérola stood out having the lowest GCA values for SFW and AUDPC indicating a higher frequency of Fop resistance alleles (Table 3). It is worth remembering that these parents were resistant to Fop and had the same GCA values. These results suggest that these parents have the same Fopresistance alleles, and that Fop-resistance is controlled by few dominant genes. For stunted growth, among the resistant parents (Table 2), VC 13 of group 1 and CVIII 8511 of group 2 had the lowest GCA values for PHR and PSWR indicating that resistant-parents VC 13 and CVIII 8511 have lower frequency of alleles responsible for stunted growth caused by the pathogen. On the other hand, parent Pérola of group 2, also classified as resistant by SFW and AUDPC, had positive GCA for PHR and PSWR, indicating a higher frequency of alleles involved in stunted growth. These results indicate that different genes are involved in genetic control on traits of Fop severity (SFW and AUDPC) and stunted growth (PHR and PSWR) in common bean. Once traits SFW and AUDPC were evaluated on the scale of disease severity ratings developed by Pastor-Corrales and Abawi (1987), the shoot wilting symptom is the main criterion. However, others symptoms such as plant growth and reduction of shoot biomass are not considered on this scale, besides happening in screening essays. Andrade et al. (2009) and Araújo and Teixeira (2012) reported that genotypes with reduced biomass production have lower grain yield. Facing these divergent results related to the performance of resistant-parents, stunted growth must also be taken into account in the selection of parents for Fusarium wilt resistance. The GCA values of parents VC 25 of group 1 and BRSMG Talismã of group 2 were lower than those of Pérola, but higher than those of parents VC 13 and CVIII 8511.

The parents VC 25 in group 1 and Pérola from group 2, in addition to being Fop-resistant, had positive GCA and high GY (Table 4), indicating a higher frequency of favorable alleles for yield in these parents. BRS Estilo and RC-I-8 also had a positive but lower GCA. The lines of VC 13 of group 1 and CVIII 8511 of group 2, despite a negative GCA for GY, are Fop-resistant and have lower GCA values for stunted growth.

\section{Specific combining ability}

For the Fop severity traits (SFW and AUDPC), the SCA values were only negative (Table 4) in hybrids derived from crosses between contrasting parents for Fop resistance $(\mathrm{R} \times \mathrm{S})$. All hybrids derived from crosses between resistant parents $(R \times R)$ had positive and equal SCA estimates. These results confirm the predominance of few genes with complete dominance in the genetic control of Fusarium wilt resistance. For the traits PHR and PSWR, the hybrid SCA estimates varied both in magnitude and in sign (Table 4), regardless of the Fop-reaction of their parents as evaluated by SFW and AUDPC, indicating greater complexity of the trait stunted growth as compared to Fop-resistance evaluated by SFW or AUDPC. Hallauer and Miranda (1988) reported that crosses involving lines with the same genetic basis have negative SCA estimates. However, for traits such as stunted growth, for which the lowest values are preferred, positive high-

Table 3. General capacity of the parents used in the partial diallel for severity of Fusarium wilt (SFW), area under the disease progress curve (AUDPC), percentage of plant height reduction (PHR), percentage of shoot fresh weight reduction (PSWR) and grain yield (GY)

\begin{tabular}{|c|c|c|c|c|c|c|}
\hline & Parents & \multirow{2}{*}{ SFW } & \multirow{2}{*}{ AUDPC } & \multirow{2}{*}{ PHR } & \multirow{2}{*}{ PSWR } & \multirow{2}{*}{ GY } \\
\hline & Group 1 & & & & & \\
\hline 1 & BRS Estilo & 1.96 & 9.47 & 12.90 & 9.21 & 44.27 \\
\hline 2 & VC 13 & -0.98 & -4.74 & -8.50 & -6.46 & -257.69 \\
\hline \multirow[t]{2}{*}{3} & VC 25 & -0.98 & -4.74 & -4.40 & -2.75 & 213.42 \\
\hline & Group 2 & & & & & \\
\hline 1 & BRSMG Talismã & -0.98 & -4.74 & -5.10 & -4.68 & -393.79 \\
\hline 2 & RC-I-8 & 1.25 & 5.86 & 0.01 & 3.25 & 137.25 \\
\hline 3 & CVIII 8511 & -0.98 & -4.74 & -7.60 & -6.91 & -95.54 \\
\hline 4 & CNFC 11965 & 1.69 & 8.35 & 8.42 & 6.81 & -104.18 \\
\hline 5 & Pérola & -0.98 & -4.74 & 4.27 & 1.53 & 456.25 \\
\hline
\end{tabular}


Table 4. Specific combining ability of parents used in the partial diallel for severity of Fusarium wilt (SFW), area under the disease progress curve (AUDPC), percentage of plant height reduction (PHR), percentage of shoot fresh weight reduction (PSWR), and grain yield (GY)

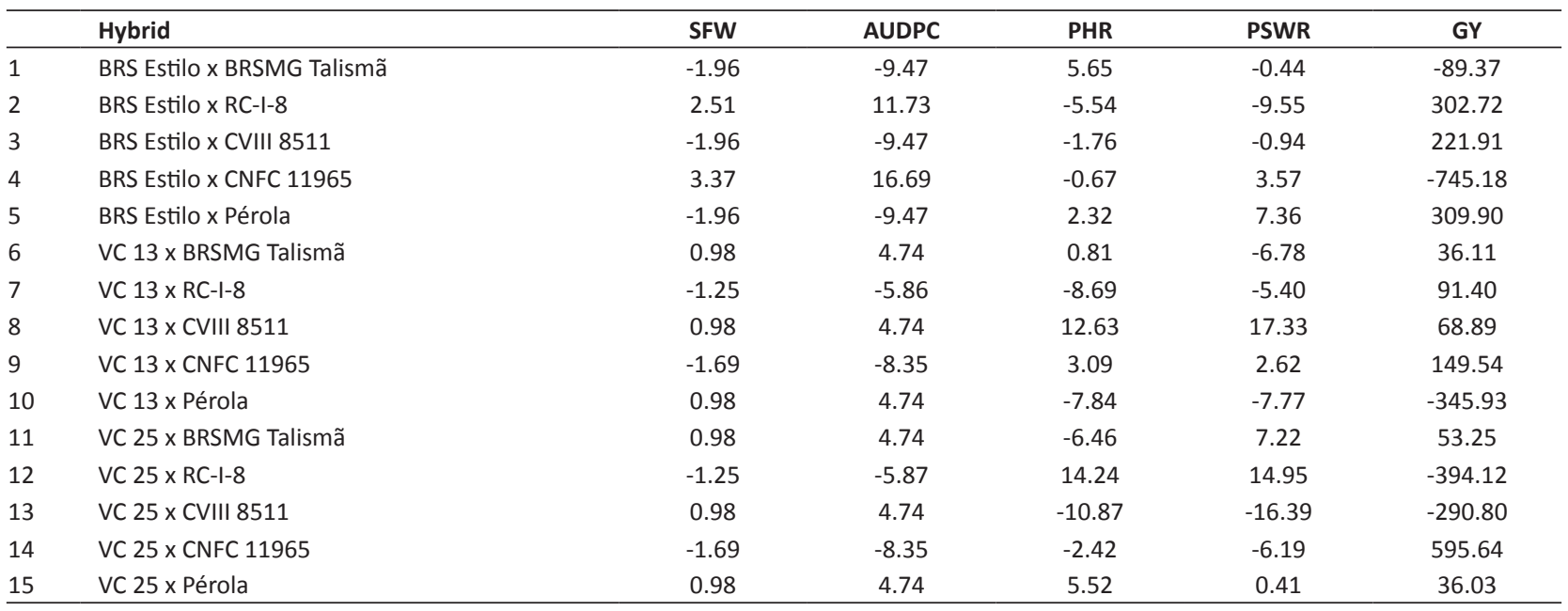

magnitude estimates indicate less divergence between the parents.

Among the hybrids obtained from crosses of resistant parents ( $R \times R$ ) with negative GCC values for stunted growth (parents with low frequency of alleles involved in stunted growth), hybrid 8 (VC 13 x CVIII 8511) had the highest SCA, and hybrid 13 (VC 25 x CVIII 8511) had the lowest SCA, indicating the low divergence of parent CVIII 8511 from parent VC 13 and high divergence from parent VC 25 for the traits PHR and PSWR.

The SCA estimate of hybrid 15 (VC 25 x Pérola) was positive for GY and its parents had the highest GCA values. This hybrid only performs well in grain yield, since no Fusarium wilt occurred in the field and the parents presented a moderate reduction in growth rate. The segregating population resulting from the cross between hybrids 13 and 15 is promising for simultaneous breeding of common bean for the traits grain yield, Fusarium wilt resistance and stunted growth.

The results of this study show that the use of the trait stunted growth as assessed by PHR and PSWR, associated with Fop-resistance by SFW and AUDPC, increases effectiveness on identification of lines that are sources of Fusarium wilt resistance as well as in choosing parents, based on diallel analysis. It is worth noting that these traits (PHR and PSWR) should be used in a diallel analysis with parents and $F_{1}$ generations, since a negative control is required to evaluate stunted growth, consisting of plants of the same genotype as those that are Fop-inoculated.

In common bean breeding, the step after choosing the segregating populations with the greatest potential for breeding of superior lines is the evaluation of inbred families, derived from these populations. These families are evaluated in two or three generations (Ramalho et al. 2001) for the traits with a more complex inheritance, including grain yield and plant architecture. At this stage, it would not be possible to evaluate stunted growth due to the lack of a negative control (plants of the same genotype). However, as there is strong evidence that severity of Fusarium wilt is controlled by a few dominant genes, the inoculation of $\mathrm{F}_{2}$ plants with Fop and breeding of resistant lines only will ensure the presence of the resistance gene in plants within the lines in later inbred generations. When breeding lines are obtained, Fop inoculation could also be used again, considering only lines with resistant plants for evaluation in field trials in different years, seasons and locations. At this stage, the Fop-resistant lines can also be assessed for the trait stunted growth, increasing the chances of success in breeding common bean for Fusarium wilt resistance.

The resistance of common bean to Fusarium wilt (isolate FOP UFV 01) is controlled by a few dominant genes, while reduction in plant growth, a response of Fop susceptibility, is governed by another set with dominant and recessive genes. Stunted growth can potentially be used to select parents and inbred common bean lines for breeding for resistance to Fusarium wilt. The segregating population, derived from the cross VC 25 / CVIII 8511 // VC 25 / Pérola, is promising for common bean breeding for the traits grain yield, resistance to Fusarium wilt and stunted growth. 


\section{ACKNOWLEDGMENTS}

This research was supported by the following Brazilian agencies: the Minas Gerais Science Foundation (FAPEMIG Fundação de Amparo à Pesquisa do Estado de Minas Gerais) and, the National Council of Scientific and Technological Development (CNPq - Conselho Nacional de Desenvolvimento Científico e Tecnológico).

\section{REFERENCES}

Alves-Santos FM, Cordeiro-Lopez L, Sayagués JM, Martín-Domingues $\mathrm{R}$, Garcia-Benavides P, Crespo MC, Días-Domingues JM and Eslava AP (2002) Pathogenicity and race characterization of Fusarium oxysporum f. sp. phaseoli isolates from Spain and Greece. Plant Pathology 51: 605-611.

Andrade CAB, Scapim CA, Braccini AL and Martorelli DT (2009) Produtividade, crescimento e partição de matéria seca em duas cultivares de feijão. Acta Scientiarum, Agronomy 31: 683-688.

Araújo AP and Teixeira MG (2012) Variabilidade dos índices de colheita de nutrientes em genótipos de feijoeiro e sua relação com a produção de grãos. Revista Brasileira de Ciência do Solo 36: 137-146.

Cândida DV, Costa JGC, Rava CA and Carneiro MS (2009) Controle genético da murcha do fusário (Fusarium oxysporum) em feijoeiro comum. Tropical Plant Pathology 34: 379-384.

Cross H, Brick MA, Schwartz HF, Panella LW and Byrne PF (2000) Inheritance of resistance to fusarium wilt in two common bean races. Crop Science 40: 954-958.

Cruz CD (2013) Genes - a software package for analysis in experimental statistics and quantitative genetics. Acta Scientiarum 35: 271-276.

Dean R, Van Kan JA, Pretorius ZA, Hammond-Kosack KE, Pietro AD, Spanu PD, Rudd JJ, Dickman M, Kahmann R, Ellis J and Foster GD (2012) The top 10 fungal pathogens in molecular plant pathology. Molecular Plant Pathology 13: 414-430.

Griffing B (1956) Concept of general and specific combining ability in relation to diallel crossing systems. Australian Journal of Biological Sciences 9: 463-493.

Hallauer AR and Miranda JB (1988) Quantitative genetics in maize breeding. $2^{\text {nd }}$ edn, lowa State University, Ames, 664p.

Madden, LV, Hughes G and Bosch FVD (2007) The study of plant disease epidemics. American Phytopathological Society, St. Paul, 421p.

Pantelides IS, Jamos SET, Pappa S, Kargakis M and Paplomatas EJ (2013)
The ethylene receptor ETR1 is required for Fusarium oxysporum pathogenicity. Plant Pathology 62: 1302-1309.

Pastor-Corrales MA and Abawi GS (1987) Reactions of selected bean germplasms to infection by Fusarium oxysporum f. sp. phaseoli. Plant Disease 71: 990-993.

Pereira AC, Cruz MFA, Paula-Júnior TJ, Rodrigues FA, Carneiro JES, Vieira RF and Carneiro PCS (2013) Infection process of Fusarium oxysporum $\mathrm{f}$. sp. phaseoli on resistant, intermediate and susceptible bean cultivars. Tropical Plant Pathology 38: 323-328.

Pereira MJZ, Ramalho MAP and Abreu AFB (2009) Inheritance of resistance to Fusarium oxysporum f. sp. phaseoli Brazilian race 2 in common bean. Scientia Agricola 66: 788-792.

Peternelli LA and Borém A (1999) Hibridação em feijão. In Borém A (ed) Hibridação artificial de plantas. UFV, Viçosa, p. 269-294.

Ramalho MAP, Abreu AFB and Santos JB (2001) Melhoramento de espécies autógamas. In Nass LL, Valois ACC, Melo IS and ValadaresInglis MC (eds) Recursos genéticos e melhoramento de plantas. Fundação MT, Rondonópolis, p. 201-230.

Ramalho MAP, Abreu AFB, Carneiro JES, Wendland A, Paula Junior TJ, Vieira RF, Del Peloso MJ, Lobo Junior M and Pereira AC (2012) Murchade-fusário. In Paula Junior TJ and Wendland A (ed) Melhoramento genético do feijoeiro-comum e prevenção de doenças. Epamig, Viçosa, p. 127-138.

Shaner G and Finney RF (1977) The effects of nitrogen fertilization on the expression of show-mildwing in knox wheat. Phytopathology 67: 1051-1055.

Toledo-Souza ED, Silveira PM, Café-Filho AC and Lobo-Júnior M (2012) Fusarium wilt incidence and common bean yield according to the preceding crop and the soil tillage system. Pesquisa Agropecuária Brasileira 47: 1031-1037.

Woo SL, Zoina A, Del Sorbo G, Lorito M, Nanni B, Scala F and Noviello C (1996) Characterization of Fusarium oxysporum f. sp. phaseoli by pathogenic races, VCGs, RFLPs, and RAPD. Phytopathology 86 : 966-973. 